\title{
Exploration and Research on Home Visiting Work of College Counselors
}

\author{
Ji Meijiao ${ }^{1, a,{ }^{*}}$, Yang Xue ${ }^{1, b}$ \\ ${ }^{1}$ Dalian University of Science and Technology, Dalian, Liaoning, China \\ a1429144363@qq.com,b793307743@qq.com
}

Keywords: College counselors, Home visits, Effective paths

\begin{abstract}
Home visits system of college counselors organically integrates family education with school education, which is an effective important way to carry out ideological and political education for college students. Through sorting out and exploring the work of college counselors' home visits, this paper studies the effective mode of college counselors' home visits, improves the effectiveness of home visits, and innovates the effective implementation path of college counselors' home visits. Colleges and universities can under the guidance of the thought of educating all people, enhance the effectiveness of home visiting from the aspects of clarifying the thinking of home visiting work, strengthening the construction of home visiting team and innovating the forms of home visiting work.
\end{abstract}

\section{Introduction}

At the National Conference on Ideological and Political Work in Colleges and Universities, General Secretary Xi Jinping emphasized that Lide Shuren should be regarded as the central link of ideological and political education. It must be carried out throughout the whole process of education and teaching, so as to realize the whole process of educating people and cultivating people in all directions, and strive to create China. We will strive to open up new prospects of the development of higher education in China. Home visits are an educational medium that can combine family education with school education. It can effectively strengthen the feasibility, effectiveness and pertinence of college students' ideological and political education. However, there are also some problems with the home counseling work of college counselors, such as the unclear purpose of home visits and the single form of home visits. Therefore, the exploration and research on strengthening the home visits of college counselors play a vital role in improving the effectiveness of home visits.

\section{The significance of college counselors' home visits}

The Central Committee of the Communist Party of China and the State Council clearly pointed out in the "Opinions on Strengthening and Improving Ideological and Political Work in Colleges and Universities under the New Situation" that "building a three-integration education network of schools, families, and societies" to form a mutual cooperation and coordination between school education, family education, and social education. The work of educating people together promotes the right of parents to participate in the education, teaching and reform of the school, the right to know and to supervise, and strive to form a synergy of education from the family, the school to the society, and work together to create a good atmosphere for the overall growth of the students.This points out the direction for further improving the home visits of college counselors.

\subsection{Home visits further enhance the pertinence of college students' ideological and political education}

The home visits of college counselors are effective ways to strengthen the communication between colleges and parents. The fundamental purpose of home visits is to understand students' family background and family status in depth, to improve the ideological and political education of college students. It is of great significance to improve the effectiveness of ideological and political education. For students with psychological problems, they can learn about the specific reasons for students' psychological problems of home visits in order to make countermeasures. For families with financial 
difficulties, they can bring hope to families through home visits, build confidence in family life, and work hard to build students. A good learning environment. Therefore, vigorously promoting the home visits of college counselors can further to enhance the pertinence of college students' ideological and political education.

\subsection{Home visits further enhance the effectiveness of ideological and political education among college students}

Home visits can be an intuitive and effective way to establish a platform for mutual communication and mutual understanding between schools and parents. It is a convenient way for counselors and parents to understand the situation of students in real time. On the one hand, through the college counselors feedback in time, parents can further understand the situation of students in school; for one thing, through communication with parents, counselors can understand students' actual difficulties, grasp the key points of problems and find out the crux of the problems. In order to better to solve the difficulties, students and parents can deepen their understanding and understand each other when they encounter problems, thus enhancing the effectiveness of the ideological and political education of college students.

\subsection{Home visits further enhance the sense of acquisition of ideological and political education among college students}

Home visits can not only create a good educational atmosphere, but also close the distance between counselors and students, and deepen the feelings of teachers and students. At the same time, such practical experience also gives the counselor a new cognitive direction, which makes him passionate about the future work, and is beneficial to the counselor to realize his own value step by step. Through the home visit, this platform can not only enhance the fit between the counselors and the students' mind, but also organically combine the educational model of the university with the educational concept of the parents, truly realize the teaching of each student according to their aptitude, and enhance the ideological and political education of college students. At the same time, it also realizes the feasibility, pertinence and effectiveness of the ideological and political work of college counselors.

\section{The effective implementation path of college counselors' home visits}

\subsection{Attach great importance of careful deployment and clarify the ideas of home visits}

Relying on the school's educational philosophy and talent training objectives, and taking the national student aided policy as the guide, and aiming at strengthening the ideological and political quality and practical work ability of college counselors, colleges and universities should attach great importance to and seriously deploy counselors' home visits and help. College counselors clarify the ideas of home visits.

3.1.1 Establish a counselor's home visit work leading group to detail the specific work of home visits In response to the documentation requirements, clear the idea of home visits: the first is to ask for awareness, and consider home visits as a key task. The second is to ask counselors to conduct a survey of students, understand the situation, and select typical and representative students. The third is to ask the counselors to clarify the contents of the home visit for the family visitors, to solve the practical difficulties of the home visitor, to be adequately prepared, and to be targeted. The fourth is to require the counselors to visit the family with strict discipline, and not to use the home visit to accept the bribe. It not only increases the burden on home-based families, but also damages the image of counselors and schools.

\subsubsection{Actively mobilize and guide the counselor to clarify the purpose of home visits}

Through active publicity and mobilization, not only the counselors' ideological and political quality and actual work level are continuously improved, but also the school's ideological and political work is closer to the students, close to reality, close to life, enhance the affinity and trust in the counselors 
and teachers, and strengthen family education. Effectively integrate with school education, improve the new mode of Trinity education, and effectively improve the effective ways of counselors' ideological and political education.

\subsection{Take multiple measures and work together to ensure effective home visits}

Universities can lay a theoretical foundation for home visits through training, enhance home visit skills through symposiums, and improve home visits through student classification management, thus ensuring effective home visits.

\subsubsection{Laying the theoretical foundation for home visit through training}

Before the annual home visit, we should carefully summarize the practical experience of the counselors' home visits over the years, train the home visit counselors in the form of training sessions, and conduct trainings on how to select home visits, clarify the purpose of home visits, and understand the meaning of home visits, and guide the counselors to understand contemporary. We should grasp the pulse of thought, and the experience of previous people for reference, and grasp the theoretical basis of home visits.

\subsubsection{Enhance the counselors' home visit skills through sharing communication}

Symposiums and exchanges with experience can effectively improve the practical skills and skills of counselors' home visits. Sharing experienced home visits with experienced counselors, and counselors brainstorming analysts' visits goals, clarifying the purpose of home visits, and developing home visit plans can continuously improve the actual work ability and work level of counselors' home visits.

\subsubsection{Improve the effect of home visits through student classification management}

According to the needs of school education management and the actual situation of students, the "three must-visit" system is implemented. Firstly, families with financial difficulties must be visited, mainly to understand the difficulties in learning and living of students with financial difficulties in their families. Secondly, students with psychological problems Family must be visited. Thirdly, families with learning difficulties must be visited, mainly to learn from students with learning difficulties through home visits. The deeper reasons are to solve the ideological problems of the students with learning difficulties and solve the academic problems.

\subsection{Innovative forms, form synergy, give full play to the function of home visits and educate people}

Home visits are an important way and effective way to do a good job in college students' ideological and political education. Through individual home visits, collective home visits, and special-time home visits, they can promote effective communication between schools and families, and form a strong synergy between school education and family education.

\subsubsection{Strengthening the targeting of home visit through personal home visits}

Most counselors take the form of personal home visits, and individual home visits are highly targeted, providing direct and scientific education guidance of the actual situation of individual students. During the home visit, I sent rice, noodles, oil and other necessities for families with financial difficulties. They also brought care and condolences to the students to help them solve their practical difficulties. More importantly, they enhanced their families through personal home visits, and strengthened confidence and courage to pass through the difficulties. For students with excellent academic performance, home visits can help them set new goals and strive for more hard work and comprehensive development.

\subsubsection{Expanding the power of home visits through collective home visits}

The use of collective home visits for students in the same area where the family is located can increase the spread of home visits. Through the "point-to-face combination" approach, "points" are typical students, and three types of must-visit students are the focus. "Face" is to expand the family visits and improve the coverage of home visits. The counselors focus on solving the problems of home visit students through collective home visits, and provide guidance opinions on the students' 
study and life in the school. They not only increase the trust of the parents of the school and the counselors, but also narrow the relationship between the counselors and the students.

3.3.3 Strengthening the effectiveness of home visits through home visits in special periods

In a special period of home visits, such as abnormal behaviors of students, family changes, outstanding psychological problems or great decline in academic performance, etc. Counselors should grasp the underlying causes of their fluctuations, and take the initiative to make home visits and communicate with students in a timely manner to understand students' difficulties, so as to help them overcome difficulties in a targeted way.

3.3.4 Diversification of home visits through telephone, internet, etc.

Today's network is developed and has entered the era of new media. WeChat, QQ, and telephone are all good ways to visit students' home. By establishing a parent WeChat group and sending a "letter to a parent" to communicate with parents as much as possible, instant media such as WeChat and QQ can contact the parents at any time and send them to the school for their concern and expectation. Let parents put forward suggestions and opinions for the ideological and political education of college students, and play the advantages of the integration of home and school and the trinity of students, schools and family education in the work, creating a favorable environment for the comprehensive and healthy development of college students.

\section{Summary}

As an effective working form of college students' ideological education, home visits have opened up new positions in ideological and political education and expanded the working space of ideological educators in colleges and universities. With this effective form the ideological and political education of college students will continue to deepen.

\section{References}

[1] Pan Mingxue, Wang Hongli, Yan, Research and exploration of college counselors' home visit work , Science and Education Wenhui (first issue) , vol.8, pp. 15-16, 2018.

[2] Yang Xue, Han Yi, Exploration on the Implementation of Home Visiting Work of College Counselors, Journal of Guangxi Youth Cadre College, vol.2, pp. 45-48, 2018.

[3] Jia Haining, Qu Changlei, Liu Zhi, Li Min. Study on the Significance, Theoretical Basis and Effective Model of College Counselors' Home Visits, Shandong Higher Education, vol.4, pp. 40-45, 2016.

[4] Zhang Shuo. Innovation of ideological and political education in home visit work of college counselors based on the concept of collaborative education , Industry and Science Forum, vol.14, pp. 161-162, 2015.

[5] Qiao Dong. The Practice and Reflections on Home Visits of College Counselors--Taking Liaoning Normal University as an Example, Journal of Economic Research, vol.13, pp. 142-143, 2019.

[6] Xu Shuiyu. Home-school linkage, collaborative education-thinking about doing a good job of counselor home visits, Journal of Chongqing Vocational College of Electronic Engineering, vol.28, pp. 75-78, 2019.

[7] Liu Tinghui. On the strategy of home visits of college counselors-Taking Chaoyang Teachers College as an example, Journal of Liaoning Teachers College (Social Science Edition), vol.3, pp. 125-127, 2018. 